\title{
Faktor risiko stunting pada anak umur 12-24 bulan
}

\author{
Wiwien Fitrie Wellina ${ }^{1}$, Martha I. Kartasurya ${ }^{2}$, M. Zen Rahfilludin ${ }^{2}$
}

\begin{abstract}
Background : In 2013, the prevalence of stunting and severe stunting in Brebes reached $26.9 \%$ and $16.8 \%$. These prevalences of stunting were higher than the stunting prevlence in Central Java Province (11.0\%). This study aimed to determine risk factors of stunting among children aged 12-24 months in Brebes District.

Methods: This research was conducted with a case-control design on 77 cases (stunting) and 77 controls (normal) in Brebes Subdistrict. Data on birth weight, birth length, infection history, pesticide exposure were obtained through interviews, using structured questionnaires. The analysis was conducted by calculating Odd Ratios and logistic regressions.

Results : Multivariate results showed that the risk factors of stunting in children aged 12-24 months in Brebes subdistrict were low energy adequacy levels (OR =7.71; 95\%CI: 3.63-16.3; $p=0.001)$, low protein adequacy levels $(O R=7.65$; 95\% CI:3.67-15.9, $p=0.001)$; low zinc adequacy levels $(O R=8.78 ; 95 \%$ CI:3.53-21.5, $p=0,001)$; low birth weight (OR=3.63; 95\%CI:1.65-7.96; $p=0.002)$ and high exposure to pesticides $(O R=8.48 ; 95 \% C I: 3.93-18.28 ; p=0,001)$. These three variables are contributing to stunting of $45 \%$. Low compliance of vitamin A capsule consumption, the frequencies of diarrhea respiratory infection were not the risk factors for stunting in this study.

Conclusions: The risk factors of stunting among children aged 12-24 months were low energy adequacy levels, low protein adequacy levels, low zinc adequacy levels, low birth weight and high exposure to pesticides. The highest risk was the high pesticide exposure.
\end{abstract}

Keywords: stunting, risk factors, energy adequacy levels, protein adequacy levels, pesticides exposure.

\begin{abstract}
ABSTRAK
Latar belakang : Pada tahun 2013 prevalensi stunting dan severe stunting adalah 26,9\% dan 16,8\%. Prevalensi tersebut lebih tinggi dibandingkan prevalensi di Jawa Tengah yang hanya sebesar 11,0\%. Penelitian ini bertujuan untuk mengetahui faktor risiko kejadian stunting pada anak umur 12-24 bulan di Kecamatan Brebes.

Metode : Penelitian ini dilakukan dengan rancangan kasus kontrol pada 77 kasus (stunting) dan 77 kontrol (normal) di Kecamatan Brebes. Data berat badan lahir, panjang badan lahir, status penyakit, pajanan pestisida diperoleh melalui wawancara mengunakan kuesioner tersuktur. Analisis dilakukan dengan Odd Ratio (OR) dan regresi logistik berganda.

Hasil : Hasil multivariat menunjukan bahwa faktor risiko yang berpengaruh terhadap kejadian stunting pada anak umur 1224 bulan di Kecamatan Brebes adalah tingkat kecukupan energi yang rendah OR=7,71 (95\% CI:3,63-16,3 p=0,001); protein yang rendah $O R=7,65$ (95\%CI:3,67-15,9 p=0,001); seng yang rendah OR=8,78 (95\%CI:3,53-21,5; $p=0,001)$, berat badan lahir rendah $O R=3,63$ (95\%CI:1,65-7,96 p=0,002) dan tingginya pajanan pestisida OR=8,48; (95\%CI:3,93-18,28 p=0,001). Kelima variabel tersebut memberikan kontribusi terhadap stunting sebesar 45\%. Ketaatan konsumsi vitamin A, frekuensi diare dan ISPA bukan merupakan faktor risiko terhadap kejadian stunting dalam penelitian ini.

Simpulan : Faktor risiko yang mempengaruhi kejadian stunting pada anak umur 12-24 bulan adalah rendahnya tingkat kecukupan energi, potein, seng, berat badan lahir rendah dan tingginya pajanan pestisida. Faktor risiko yang paling besar terhadap kejadian stunting adalah tingginya pajanan pestisida.
\end{abstract}

Kata kunci : stunting, faktor risiko, tingkat kecukupan energi, pajanan pestisida.

\section{PENDAHULUAN}

Stunting merupakan keadaan tubuh yang pendek menurut umur hingga melampaui defisit -2 SB dibawah median standar panjang atau tinggi badan menurut umur. ${ }^{2}$ telah diketahui bahwa semua masalah anak pendek, bermula pada proses tumbuh kembang janin dalam kandungan sampai usia 2 tahun. Apabila dihitung dari sejak hari pertama kehamilan, kelahiran bayi sampai anak usia 2 tahun merupakan periode

\footnotetext{
1. Departemen Ilmu Gizi, Fakultas Kedokteran, Universitas Diponegoro, Semarang

2. Fakultas Kesehatan Masyarakat, Universitas Diponegoro, Semarang (email korespondensi: m_kartasurya@yahoo.com)
}

1000 hari pertama kehidupan manusia, disebut sebagai window opportunity. ${ }^{1}$

Prevalensi stunting menurut Rikesdas 2013 angka nasional sebesar 37,2\% yang berarti adanya peningkatan dibandingkan tahun 2007 (36,8\%). Prevalensi stunting di Provinsi Jawa Tengah yaitu sebesar 28,6\% dimana untuk kategori sangat pendek $11,0 \%$ sedangkan prevalensi di Kabupaten Brebes untuk kategori sangat pendek sebesar 16,8\% angka ini melebihi prevalensi stunting di Jawa Tengah.

Salah satu faktor risiko kejadian Stunting kurangnya asupan gizi dalam jangka waktu yang lama, sehingga dapat terjadi perlambatan pertumbuhan dan berpengaruh terhadap status gizi. Penyakit infeksi ( diare dan ISPA ) dapat 
mengakibatkan berat badan turun secara akut dan berpengaruh pada status gizi balita bila terjadi dalam jangka waktu yang lama. Balita dengan status gizi yang kurang mempunyai sistem imun yang rendah yang dapat membuat balita mudah terkena penyakit infeksi.

Anak dengan defisiensi vitamin A memiliki kecenderungan stunting karena pada masa anak-anak vitamin A mempengaruhi pertumbuhan dan perkembangan sel, apabila terjadi defisiensi dapat merusak sistem kekebalan tubuh dan dapat meningkatkan risiko infeki seperti penyakit campak dan diare.

Paparan pestisida yang diterima oleh ibu hamil dapat juga menjadikan bayinya stunting. Beberapa jenis pestisida dikenal sebagai thyroid disrupting chemicals (TDCs), dapat mengganggu struktur dan fungsi kelenjar tiroid, mengganggu sintesis, sekresi, transpor, pengikatan dan eliminasi hormon tiroid, yang berdampak terjadinya hipotiroidisme. Hipotiroidisme pada ibu hamil menyebabkan terjadinya gangguan tumbuh-kembang janin/anak yang dilahirkannya.

\section{BAHAN DAN METODE}

Desain penelitian yang digunakan adalah kasus kontrol,dengan kriteria inklusi anak berusia 12-24 bulan, diwilayah kerja puskesmas Brebes Kabupaten Brebes, lahir cukup bulan, orang tua bersedia menjadi responden, subjek sejumlah 77 anak stunting dan 77 anak tidak stunting untuk kontrol, yang diambil dengan mengunakan metode Multi Stage Sampling meliputi dua tahap yaitu Purposive dengan memilih dua desa yang memiliki karateristik yang sama seperti tingkat ekonomi, pola makan, dan banyaknya jumlah responden, kemudian Propotional Random Sampling diambil jumlah sampel sesuai kebutuhan berdasarkan proposinya dengan cara diundi dan dilakukan matching terhadap kelompok jenis kelamin dan umur.

Variabel terikat dalam penelitian ini adalah stunting, sedangkan variable bebas adalah tingkat kecukupan energi, protein, seng, ketaatan konsumsi kapsul vitamin A, status penyakit infeksi (diare,ISPA), berat badan lahir dan pajanan pestisida. Data yang dikumpulkan diperoleh dengan menggunakan alat bantu yaitu infantometer untuk mengukur panjang badan. Berat badan lahir dilihat dari buku KIA, riwayat penyakit diare, ISPA, paparan pestisida diperoleh melalui wawancara dengan kuesioner. Data asupan energi dan protein anak diperoleh melalui food recall kepada ibu. Data dianalisis secara univariat, bivariat, chi-squre, dilanjutkan dengan metode regresi logistik berganda.

\section{HASIL}

\section{Karateristik subjek}

Tabel 1. menunjukkan sebagian besar subjek berjenis kelamin perempuan. jumlah subjek yang memiliki berat badan lahir rendah lebih besar pada kelompok kasus dibandingkan dengan kelompok kontrol. Pada kelompok kasus sebagian besar subjek memiliki panjang badan lahir kurang dari normal. Pada kasus kontrol sebagian besar memiliki panjang badan lahir yang normal.

\section{Deskripsi Tingkat Kecukupan Energi, Protein, Seng, Vitamin A pada anak Stunting dan Normal}

Tingkat kecukupan energi, protein dan seng dikategorikan menjadi dua yaitu, cukup dan kurang, dikategorikan kurang apabila $<80 \%$ AKG, dan dikatakan cukup jika $\geq 80 \%$. Tabel 2 menunjukan tingkat kecukupan energi, protein, seng yang kurang pada anak stunting berurutan sebesar $83,1 \%$; 80,5\%; $91,1 \%$. sedangkan pada anak yang normal terdapat tingkat kecukupan energi, protein dan seng yang baik berurutan sebesar 61,1\%; 65,0\%; 47,4\%. Anak stunting memiliki ketaatan yang baik dalam mengkonsumsi vitamin A yaitu sebesar 72,7\% dibandingkan dengan anak normal yang memiliki ketaatan mengkonsumsi vitamin A sebesar 63,6\%.

Penelitian menunjukkan anak yang tingkat kecukupan energi, protein, seng dalam kategori kurang berisiko menjadi stunting dilihat dari $\mathrm{p}<0,005$ yang berarti ada hubungan bermakna TKE $(\mathrm{p}=0,001)$, TKP $(p=0,001)$, TK Seng $(p=0,001)$ sedangkan ketaatan dalam mengkonsumsi vitamin A yang sesuai umur bukan merupakan faktor risiko dimana $\mathrm{p}=0,299$.

Tabel 2 menunjukkan bahwa factor risiko terjadinya stunting adalah kurangnya asupan energy, protein dan seng. Baduta yang tingkat energinya kurang memiliki kemungkinan menjadi stunting yaitu sebesar 7,71 kali di bandingkan dengan baduta yang tingkat kecukupan energinya baik. Baduta yang tingkat kecukupan proteinnya kurang memiliki kemungkinan menjadi stunting sebesar 7,65 kali dibandingkan dengan baduta yang tingkat kecukupan proteinnya baik. Baduta yang tingkat kecukupan sengnya rendah memiliki peluang stunting sebesar 8,78 kali dibandingkan dengan baduta yang tingkat kecukupan sengnya baik. Ketaatan dalam konsumsi kapsul vitamin A bukan merupakan faktor risiko stunting pada penelitian ini. 
Tabel 1. Karakteristik Subjek

\begin{tabular}{|c|c|c|c|c|c|c|c|c|c|c|}
\hline \multirow{2}{*}{$\begin{array}{c}\text { Karakteristik } \\
\text { Subjek }\end{array}$} & \multirow[b]{2}{*}{$\mathbf{n}$} & \multirow[b]{2}{*}{$\%$} & \multicolumn{3}{|c|}{ Anak Stunting } & \multicolumn{3}{|c|}{ Anak Normal } & \multirow[b]{2}{*}{ Min } & \multirow[b]{2}{*}{ Maks } \\
\hline & & & x SB & Min & Maks & $\mathbf{n}$ & $\%$ & $\mathbf{x}$ SB & & \\
\hline \multicolumn{11}{|l|}{ Jenis Kel } \\
\hline Laki-laki & 35 & 45,4 & & & & 36 & 46,8 & & & \\
\hline Perempuan & 42 & 54,6 & & & & 41 & 53,2 & & & \\
\hline \multicolumn{11}{|l|}{ Umur (bln) } \\
\hline$<18$ & 51 & 66,2 & $15,00 \pm 4,17$ & 12 & 24 & 36 & 46,8 & $18.00 \pm 3,99$ & 12 & 24 \\
\hline$\geq 18$ & 26 & 33,8 & & & & 41 & 53,2 & & & \\
\hline \multicolumn{11}{|l|}{ PB̄ $\overline{\mathbf{L}}(\mathbf{c m})$} \\
\hline$<50 \mathrm{~cm}$ & 57 & 74,1 & $50 \pm 1,22$ & 46 & 51 & 24 & 31,2 & $50 \pm 0,97$ & 48 & 51 \\
\hline$>50 \mathrm{~cm}$ & 20 & 25,9 & & & & 53 & 68,8 & & & \\
\hline \multicolumn{11}{|l|}{ BB Lahir (g) } \\
\hline BBLR & 29 & 37,7 & $2700 \pm 4712$ & 2000 & 3800 & 11 & 14,3 & $3000 \pm 36,32$ & 220 & 3800 \\
\hline Normal & 48 & 62,3 & & & & 66 & 85,7 & & & \\
\hline
\end{tabular}

Tabel 2. Deskripsi Tingkat Kecukupan Energi, Protein, Seng, Vit A pada anak Stunting dan Normal

\begin{tabular}{cllllll}
\hline Tingkat Kecukupan & \multicolumn{2}{l}{ Stunting } & \multicolumn{5}{l}{ Normal } & \\
\cline { 2 - 7 } & $\mathrm{n}$ & $\%$ & $\mathrm{n}$ & $\%$ & OR(95\%CI) & $\mathrm{p}$ \\
\hline Energi Kurang & 64 & 83,1 & 30 & 38,9 & 7,71 & 0,001 \\
Baik & 13 & 16,9 & 47 & 61,1 & $(3,63-16,3)$ & \\
Protein Kurang & 62 & 80,5 & 27 & 35,0 & 7,65 & 0,001 \\
Baik & 15 & 19,6 & 50 & 65,0 & $(3,67-15,9)$ & \\
Seng Kurang & 70 & 91,1 & 41 & 52,6 & 8,78 & 0,001 \\
Baik & 7 & 8.9 & 36 & 47,4 & $(3,58-21,5)$ & \\
Vitamin A kurang & 56 & 72,7 & 49 & 63,6 & 1,52 & 0,299 \\
Baik & 21 & 27,3 & 28 & 36,4 & $(0,76-3,01)$ & \\
\hline
\end{tabular}

Tabel 3 Deskripsi Berat Badan dan Panjang Badan Lahir pada anak Stunting dan Normal

\begin{tabular}{|c|c|c|c|c|c|c|}
\hline & \multicolumn{2}{|c|}{ Stunting } & \multicolumn{2}{|c|}{ Normal } & \multirow[t]{2}{*}{ OR $(95 \% \mathrm{CI})$} & \multirow[t]{2}{*}{$\mathrm{p}$} \\
\hline & $\mathrm{n}$ & $\%$ & $\mathrm{n}$ & $\%$ & & \\
\hline \multicolumn{7}{|l|}{ Berat Badan Lahir } \\
\hline Rendah & 29 & 37,7 & 11 & 14,9 & 3,63 & 0,002 \\
\hline Normal & 48 & 62,3 & 66 & 85,7 & $(1,65-7,96)$ & \\
\hline Panjang Badan Lahir & & & & 74,0 & & \\
\hline Pendek & 57 & 74,1 & 24 & 31,2 & 6,29 & 0,001 \\
\hline Normal & 20 & 25,9 & 53 & 68,8 & $(3,12-12,6)$ & \\
\hline
\end{tabular}

Tabel 4 Deskripsi Frekuensi Diare, ISPA, Pajanan Pestisida

\begin{tabular}{|c|c|c|c|c|c|c|}
\hline \multirow{2}{*}{$\begin{array}{l}\text { Tingkat } \\
\text { Kecukupan }\end{array}$} & \multicolumn{2}{|c|}{ Stunting } & \multicolumn{4}{|c|}{ Normal } \\
\hline & $\mathrm{n}$ & $\%$ & $\mathrm{n}$ & $\%$ & OR(95\%CI) & $\mathrm{p}$ \\
\hline \multicolumn{7}{|c|}{ Frekuensi Diare } \\
\hline Sering & 12 & 15,6 & 8 & 10,4 & \multirow{3}{*}{$\begin{array}{l}1,59 \\
(0,24-1,63)\end{array}$} & \\
\hline Jarang & 65 & 84,4 & 69 & 89,6 & & 0,47 \\
\hline \multicolumn{6}{|c|}{ Frekuensi ISPA } & \\
\hline Sering & 11 & 14,3 & 20 & 26,0 & \multirow{3}{*}{$\begin{array}{l}2,105 \\
(0,93-4,76)\end{array}$} & \multirow{3}{*}{0,05} \\
\hline Jarang & 66 & 85,7 & 57 & 74,0 & & \\
\hline \multicolumn{5}{|l|}{ Pajanan } & & \\
\hline Pestisida & & & & & \multirow{3}{*}{$\begin{array}{l}8,48 \\
(3,93-18,28)\end{array}$} & \\
\hline Sering & 47 & 61,0 & 12 & 15,6 & & \multirow[b]{2}{*}{0,001} \\
\hline Jarang & 30 & 39,0 & 65 & 84,4 & & \\
\hline
\end{tabular}


Tabel 5 Hasil Uji Regresi Logistik Ganda

\begin{tabular}{lllllll}
\hline No & Variabel & B & SE & P & OR & $95 \%$ CI \\
\hline 1. & Tingkat kecukupan Energi & $-1,477$ & 0,461 & 0,001 & 0,228 & $0,092-0,564$ \\
2 & Tingkat kecukupan protein & $-1,421$ & 0,449 & 0,002 & 0,242 & $0,100-0-582$ \\
3 & Pajanan pestisida & $-2,093$ & 0.463 & 0,001 & 0,123 & $0,050-0,305$ \\
& & & & & & \\
\hline
\end{tabular}

Deskripsi Berat Badan Lahir dan Panjang Badan Lahir

Hasil analisa hubungan antara berat badan lahir dengan stunting didapatkan bahwa proposi baduta dengan berat badan lahir rendah lebih cenderung menjadi stunting yaitu sebesar 3,63 kali dibandingkan dengan baduta yang berat badan lahirnya normal. Baduta dengan panjang badan lahir rendah mempunyai risiko 6,29 kali lebih besar untuk menjadi stunting daripada baduta dengan panjang badan lahir normal.

\section{Deskripsi Status Infeksi Diare, ISPA, Pajanan Pestisida}

Riwayat infeksi diare dan ISPA bukan faktor risiko stunting pada anak umur 12-24 bulan. Sedangkan Baduta yang sering terpajan pestisida mempunyai risiko 8,48 kali lebih besar untuk menjadi stunting dibandingkan yang jarang terpajan pestisida.

Analisis multivariat dilakukan dengan tujuan mengetahui variabel bebas apa saja yang menjadi prediktor terjadinya stunting. Variabel independen yang tidak berpengaruh secara otomatis akan dikeluarkan dari perhitungan. Variabel yang dijadikan kandidat dalam uji regresi logistik ini adalah variabel yang dalam analisis bivariat mempunyai nilai $\mathrm{p} \leq 0,25$, yang berjumlah 8 variabel yaitu tingkat kecukupan energi, tingkat kecukupan protein, tingkat kecukupan seng, konsumsi vitamin A, berat badan lahir, frekuensi diare, frekuensi ISPA, pajanan pestisida. Seluruh variabel dimasukan dalam uji regresi, dengan sistem enter variabel yang tidak memiliki $p \leq 0,25$ akan dikeluarkan satu persatu, ada tiga vriabel independen yang merupakan predictor dari terjadinya stunting yaitu tingkat kecukupan energi, tingkat kecukupan seng, dan pajanan pestisida.

\section{PEMBAHASAN}

Kurangnya asupan energi, protein dan seng merupakan faktor risiko terjadinya stunting pada penelitian ini. Menurut hasil penelitian di Kabupaten Bogor menunjukan bahwa tingkat asupan energi kelompok anak normal hampir sebagian tercukupi, sementara pada kelompok anak stunting masih rendah. ${ }^{36,37,38}$ Pada penelitian di Kalimantan Barat dan Maluku, diperoleh hasil bahwa konsumsi energi berhubungan dengan kejadian stunting pada balita. 39,40

Penelitian yang dilakukan pada anak sekolah di Brazil menunjukan tidak adekuatnya asupan protein berhubungan signifikan dengan kejadian stunting. ${ }^{35}$ Pada anak usia 2 - 5 tahun di Kenya dan Nigeria asupan protein yang tidak adekuat berhubungan dengan kejadian stunting. ${ }^{42}$ Berdasarkan analisis data RISKESDAS 2010 di provinsi yang berbeda, terdapat hubungan signifikan antara konsumsi protein dengan kejadian stunting pada balita. ${ }^{33,43}$

Defisiensi seng akan menyebabkan perubahan pada beberapa sistem organ seperti sistem saraf pusat, saluran pencernaan, sistem reproduksi dan fungsi pertahanan tubuh baik. Faktor predisposisi terjadinya defisiensi seng adalah karena: a. Konsumsi dan absorbsi kurang, b. Meningkatnya pengeluaran, c. Utilisasi kurang, d. Kebutuhan meningkat. Manifestasi defisiensi $\mathrm{Zn}$ yang khas pada anak adalah keterlambatan pertumbuhan.

Defisiensi seng ringan dapat diberikan dengan suplementasi seng 2-3 kali dari recommended dietary allowance (RDA), sedangkan defisiensi sedang atau berat dapat diberikan 4-5 dari RDA (Saper RB dan Rash r, 2009) sedangkan anjuran WHO(1996) yaitu batas tertinggi yang aman untuk anak usia 0,5-1 tahun sebesar $3 \mathrm{mg} /$ hari, sedangkan untuk usia 1-6 tahun sebesar $23 \mathrm{mg} /$ hari.

Interaksi antara seng dan jenis mineral lainnya atau dengan vitamin dapat membantu dan menghambat absorpsi Zn. Makanan tinggi kalsium dan besi dapat meningkatkan hilangnya seng di dalam saluran cerna. Forbes dan Likushi menenukan bahwa kalsium akan menurunkan penyerapan $\mathrm{Zn}$ pada tikus. Namun beberapa studi pada manusia telah menunjukan bahwa konsumsi $500 \mathrm{mg}$ sampai $22 \mathrm{~g}$ kalsium seperti kalsium karbonat hidrosipatit atau kalsium sitrat malat tidak berpengaruh pada absorpsi seng.

Dalam meta analisis yang dilakukan oleh Nasution (2004) menunjukkan bahwa pemberian suplementasi $\mathrm{Zn}$ dan Besi dengan dosis yang sesuai dapat memberikan efek yang positif terhadap pertumbuhan anak.

Anak usia 12-24 bulan mempunyai risiko mengalami anemia defisiensi besi karena meningkatnya kebutuhan zat besi serta makanan yang tidak cukup mengandung zat besi. Disamping itu, 
anemia defisiensi besi merupakan faktor risiko terjadinya defisiensi seng. Interaksi zat besi dan seng berdampak pada hambatan pertumbuhan tinggi badan sehingga anak terlahir pendek. Defisiensi seng dapat mengakibatkan gagal tumbuh, penurunan nafsu makan, dan penyembuhan luka yang lambat. ${ }^{22}$

Makanan sumber seng yang paling baik adalah yang berasal dari sumber protein hewani, seperti daging, hati, kerang, telur. Serelia tumbuk dan kacang kacangan juga merupakan sumber seng yang baik, namun mempunyai ketersediaan biologik yang rendah. ${ }^{32}$ Selain dari makanan, seng juga dapat diperoleh dari cairan pencernaan yang berasal dari pangkreas. ${ }^{15}$ Batas konsumsi seng adalah $40 \mathrm{mg} / \mathrm{hari}$. Konsumsi seng yang berlebihan dapat perasaan tidak enak diperut, lambung terganggu, mual, gelisah, pusing, dan diare.

Di Indonesia, angka nasional untuk mengetahui prevalensi defisiensi seng sampai saat ini belum diketahui tetapi berdasarkan penelitian yang pernah dilakukan diketahui pada tahun 2006 balita indonesia mengalami defisiensi seng sebesar $31,6 \%$. Anak yang mendapat suplemen seng kenaikan pertumbuhanya lebih besar dari pada anak dalam kelompok kontrol yang tidak mendapat suplemen seng.

Ketaatan konsumsi kapsul vitamin A bukan merupakan faktor risiko terjadinya stunting pada penelitian ini. Namun hasil penelitian ini menunjukkan bahwa $72,7 \% \quad(\mathrm{n}=56)$ baduta yang kurang taat konsumsi vitamin A mengalami stunting dan angka tersebut lebih besar dibandingkan baduta yang normal.

Efek vitamin A pada pembangunan di tingkat kehidupan dimulai pada awal embriogenesis, ketika vitamin A berperan morphogenetic mendasar dalam organisasi embrio. Vitamin A adalah salah satu sinyal bahwa bagian tertentu langsung dari embrio untuk berkembang menjadi anggota badan, tubuh, dan sistem saraf. Masa kanak-kanak, vitamin A terus mempengaruhi pertumbuhan dan perkembangan yang mendalam secara langsung. Kekurangan vitamin A dapat merusak fungsi dari sistem kekebalan tubuh dan meningkatkan risiko infeksi serius,seperti penyakit campak dan diare. Pada masa pertumbuhan anak sering terjadi KEP, defisinsi vitamin A, serta defisiensi mikronutrien seperti besi, seng ( $\mathrm{Zn}$ ), yodium, kalsium, dan tembaga, yang berdampak pada penurunan status gizi. Kekurangan vitamin A juga dapat menyebabkan gangguan pertumbuhan.

Hasil uji statistik menunjukan adanya ada hubungan yang bermakna antara berat badan lahir rendah dengan stunting. Hasil penelitian ini sesuai dengan penelitian sebelumnya, yang menyimpulkan bahwa riwayat Berat Badan Lahir Rendah mempengaruhi kejadian stunting pada anak 1-2 tahun
( $\mathrm{p}=0,002, \mathrm{OR}=1,75 ; 95 \%$ CI: 1, 09-2,29). ${ }^{15}$ BBLR menandakan janin mengalami malnutrisi didalam kandungan, dan stunting di akibatkan oleh malnutrisi yang lama. ${ }^{27}$

Di negara berkembang bayi dengan berat lahir rendah (BBLR) lebih cenderung mengalami retardasi pertumbuhan intrauteri yang terjadi karena buruknya gizi ibu dan meningkatnya angka infeksi dibandingkan dengan negara maju. ${ }^{37}$ Bayi yang lahir dengan berat badan kurang dari normal (<2500gram) mungkin masih memiliki panjang badan normal pada waktu dilahirkan. Stunting baru akan terjadi beberapa bulan kemudian, walaupun hal ini sering tidak disadari oleh orang tua. Orang tua baru mengetahui anaknya stunting setelah anaknya mulai bergaul dengan teman-temannya, sehingga terlihat anak lebih pendek dibandingkan temannya. Oleh karena itu anak yang lahir dengan berat badan kurang dibawah normal harus diwaspadai akan menjadi stunting. Semakin awal dilakukan penangulangan malnutrisi, maka akan semakin kecil resiko menjadi stunting.

Bagi perempuan yang lahir dengan berat rendah, memiliki risiko besar untuk menjadi ibu yang stunted akan cenderung melahirkan bayi dengan berat lahir rendah sepeti dirinya. Bayi yang dilahirkan oleh ibu stunted tersebut akan menjadi perempuan dewasa yang stunted juga, dan akan membentuk siklus sama seperti sebelumnya. ${ }^{18}$

Semua kelompok lahir berisiko terhadap stunting hingga usia 12 bulan, dengan risiko terbesar pada kelompok anak IUGR (Intra Uterine Growth Retardation) dan risiko terkecil pada kelompok anak normal. Pada kelompok IUGR berkontribusi terhadap siklus intergenerasi yang disebabkan oleh tingkat ekonomi rendah, penyakit dan defisiensi zat gizi. Hal tersebut menunjukan bahwa, ibu dengan gizi kurang sejak awal sampai dengan akhir kehamilan akan melahirkan BBLR, yang kedepannya akan menjadi anak stunting. ${ }^{3}$

Peneliti lain menyatakan berat badan lahir dengan status gizi rendah di kabupaten dan kotamadya Sumedang, propinsi Jawa Barat menyimpulkan bahwa bayi dengan berat badan lahir rendah mempunyai risiko KEP 10,2 kali dibandingkan dengan berat bayi lahir normal.

Dalam penelitian lain, berat lahir rendah telah diketahui berkorelasi dengan stunting. Dalam analisis multivariant tunggal variabel berat lahir rendah dapat bertahan, hal ini menunjukan bahwa berat lahir rendah memiliki efek yang besar terhadap stunting. Seperti yang telah diketahui sebelumnya, efek dari berat lahir rendah terhadap kesehatan anak adalah faktor yang paling relevan untuk kelangsungan hidup anak. ${ }^{46}$

Riwayat infeksi diare dan ISPA bukan faktor risiko stunting pada anak umur 12-24 bulan. Berbeda dengan penelitian sebelumnya yang menyimpulkan 
bahwa kejadian stunting meningkat secara signifikan dengan adanya penyakit diare dan ISPA. ${ }^{15}$ Riwayat infeksi pada penelitian ini didefinisikan sebagai adanya penyakit diare atau ISPA yang kronis (perjalanan penyakit lebih dari dua minggu). Bisa saja infeksi bersifat akut tetapi terjadi setiap bulan. Tidak adanya hubungan yang bermakna antara riwayat infeksi dengan kejadian stunting pada penelitian ini kemungkinan disebabkan karena definisi infeksi yang terlalu luas sehingga infeksi yang ringan masuk dalam definisi tersebut. Penyakit infeksi ringan seperti infeksi saluran pernafasan atas sering terjadi pada anak karena penyakit ini sangat mudah menular. Namun penyakit ini dapat sembuh sendiri dalam waktu relatif cepat sehingga tidak sampai menurunkan status gizi.

Faktor-faktor yang mempengaruhi status gizi anak balita yaitu penyebab langsung dan tidak langsung, makanan dan penyakit dapat secara langsung menyebabkan gizi kurang, timbulnya gizi kurang tidak hanya disebabkan karena asupan makanan yang kurang, tetapi juga penyakit. Demikian pula pada anak yang tidak memperoleh cukup makan, maka daya tahan tubuhnya akan melemah dan akan mudah terserang penyakit

Selain itu, pajanan pestisida juga merupakan faktor risiko stunting pada penelitian ini. Penelitian terdahulu menyimpulkan bahwa anak yang sering terpajan pestisida berisiko menjadi stunting $\mathrm{OR}=1,34$ $\mathrm{CI}=0,69-1,4.34 \quad$ Sedangkan sebagian besar subjek pada penelitian ini terpapar oleh pajanan pestisida.

Paparan pestisida yang diterima oleh ibu hamil dapat juga menjadikan bayinya stunting. Beberapa jenis pestisida dikenal sebagai thyroid disrupting chemicals (TDCs), yaitu bahan kimia di lingkungan yang dapat mengganggu struktur dan fungsi kelenjar tiroid, mengganggu sintesis, sekresi, transpor, pengikatan dan eliminasi hormon tiroid, yang berdampak terjadinya hipotiroidisme. Hipotiroidisme pada ibu hamil menyebabkan terjadinya gangguan tumbuh-kembang janin/anak yang dilahirkannya dan diduga merupakan penyebab utama terjadinya peningkatan kasus anakanak dengan kebutuhan khusus, seperti attention deficit hyperactivity disorder (ADHD) atau autisme. Penelitian di Belanda membuktikan bahwa anak yang dilahirkan oleh ibu yang menderita hipotiroidisme mempunyai skor tumbuh-kembang lebih rendah dibanding kelompok kontrol. Pada bayi/anak, hipotiroidisme menyebabkan gangguan kecerdasan dan menurunnya kemampuan akademik mereka.

Beberapa penelitian membuktikan bahwa pajanan pestisida berdampak negatif terhadap fungsi kelenjar tiroid. Penelitian yang dilakukan oleh Sungkawa H.B. tahun 2008 pada petani hortikultura di
Kecamatan Ngablak Kabupaten Magelang, disimpulkan bahwa faktor risiko masa kerja petani, lama kerja per hari, jenis pestisida, frekuensi penyemprotan, posisi terhadap arah angin, dan penggunaan alat pelindung diri berpengaruh terhadap kejadian goiter dengan probabilitas sebesar $33,78 \% .{ }^{14}$

\section{KETERBATASAN PENELITIAN}

Pada penelitian ini terdapat keterbatasanketerbatasan yang bisa dijadikan bahan pertimbangan, tidak semua faktor yang mempengaruhi stunting diteliti seperti genetik, hormonal, riwayat ASI ekslusif, MP-ASI, pola asuh. Data didapat dalam waktu yang bersamaan. Oleh karena itu, disain ini sulit mengetahui variabel mana yang terlebih dahulu menjadi penyebab atau akibat.

\section{SIMPULAN}

Faktor risiko yang mempengaruhi kejadian stunting pada anak umur 12-24 bulan adalah rendahnya tingkat kecukupan energi, potein, seng, berat badan lahir rendah dan tingginya pajanan pestisida. Namun yang lebih beresiko terhadap kejadian stunting adalah tingginya pajanan pestisida.

\section{DAFTAR PUSTAKA}

1. Hendriks KM. Manual of Pediatric Nutrition. Hamilton: BC Decker, 2005. P:8-52.

2. Badan Penelitian dan Pengembangan Kesehatan. Riset Kesehatan Dasar (RISKESDAS) 2013.p: 212.

3. Lameshow S, Horsner D, Klar J, Lwanga S. Besar Sampel dalam Penelitian Kesehatan. Yogyakarta : Gajahmada University Press; 1997 p: 24-6.

4. Candra A., Puruhita N, Susanto CJ, Risk Factor of Stunting among 1-2 Years Old Children in Semarang City. Media Medika Indonesia 2011. Vol 45 No 3. P : 206-2011.

5. Zottareli LK, Sunil TS, Rajaram S. Influence of parentral and sosioeconomic factor on stunting in children under yearin Egypt. Eastem Mediterranean Health Journal (internet). 2007 (cited 2013 October 16). Available from: htt://www.emro.who.int/emhj/1306.

6. Fatimah S. Dampak Berat Badan Lahir terhadap Status Gizi Bayi. Jakarta. Badan Litbang Kesehatan 2009. P: 10-16.

7. Anugraheni HS. Faktor Risiko Kejadian Stunting pada Anak Usia 12-36 Bulan di Kecamatan Pati, Kabupaten Pati. 2012. Program Studi Ilmu Gizi Fakultas Kedokteran Universitas Diponegoro Semarang.Tesis p: 30-37. 
8. Supariasa IDN, Bachyar B, Ibnu F. Penilaian Status Gizi : EGC; 2002. p: 18-188

9. Savage King F, Burgess. Nutrition for Developing Countries. Oxford Medical Publikasi. 1996. P: 147

10. Hidayati L, Hadi H, Kumara A. Kekurangan Energi dan Zat Gizi Merupakan Faktor Risiko Kejadian Stunted pada Anak Usia 1-3 Tahun. Jurnal Kesehata. Juni 2010. p: 98-104.

11.Branca, Francesco. Nutritional Solutions to Major Health Problem of Preschool Children. How to Optimisme Growth and Development. Journal of Pediatric Gastroenterology and Nutrition. 2006.Vol. 43 p::S4-S7.

12. Arisman. Buku Ajar Ilmu Gizi. Gizi dalam Daur Kehidupan .Jakarta Penerbit: EGC. 2009. P: 26-37

13.Sedgh, Gilda, et al. Dietary Vitamin A Intake and Nondietary Factors Are Associated with Reversal of Stunting in Children. The Journal of Nutrition. 2000. 130: 2520-2525.

14.Hunt JM. Investing in Children. Child Protection and Economic Growth. Asian Development Bank. 2005. 83: 777-784.

15.Kusharisupeni. Growth Faltering pada Bayi di Kabupaten Indramayu Jawa Barat. Makara Kesehatan. 2002; 6: 1-5

16.Semba R.D., et al. Effect of Parenteral Formal Education on Risk of Child Stunting in Indonesia and Bangladesh: A Cross Sectional Study. The Lancet Articel. 2008371 p: 322-328.

17.Azwar S. Sikap Manusia Teori dan Pengukurannya. Yogyakarta: Pustaka Pelajar. 2008. 156.

18. USAID. Nutrition Assessment For 2010 New Project Design. 2010.

19.UNSCN. $6^{\text {th }}$ Report on The World Nutrition Situation. Progress in Nutrition. 2008. 8-60.

20.Narendra. M. B.et al Tumbuh Kembang Anak dan Remaja. Sagung Seto. Jakarta 2002. 8-19.

21. Gibson R.S. Principles of Nutritional Assessment. New York Oxford University Press, Inc. 2005. 1684-537.

22.Khaldun, Syamsu. Z-Skor Status Gizi Balita di Provinsi Sulawesi Selatan. 2008. 112-125.

23. Najahah I, Adhi KT. Faktor Risiko Balita Stunting Usia 12-36 Bulan di Puskesmas Dasan Agung Mataram Provinsi Nusa Tenggara Barat. 2013. 134-141.

24.Fund UNC. World Healt Organization. The World Bank UNICEF-WHO-World Bank Joint Child Malnutrisi Estimates. 2012. P:8-52.

28.Indriyani. Hubungan antara Pola Asuh Gizi dan Faktor Lain dengan status Gizi Balita(12-59) bulan di Kelurahan Sindangrasa Bogor. Artikel Penelitian FKM UI. 2011. p:
29.Ramli, et al. Prevalence and Risk Factor For Stunting and Severe Stunting Among UnderFives in North Maluku Province of Indonesia. BMC Pediatric 2009, 9: 64.

30.Astari, L.D.,A. Nasoetion, dan C. M. Dwiriani. Hubungan Karateristik Keluarga, Pola Pengasuhan, dan Kejadian Stunting Anak Usia 6-12 Bulan. 2006 Media Gizi dan Keluarga.2006; 30:15-23.

31.Asrar, M.,H. Hadi, \& D. Boediman. Pola asuh, Pola Makan, Asupan Zat Gizi, dan Hubungannya dengan Status Gizi Anak Balita Masyarakat Suku Nuaulu di Kecamatan Amahai Kabupaten Maluku Tengah Provinsi Maluku. Jurnal Gizi Klinik Indonesia. 200. 84-94.

32.Taguri, A.E., et al. Risk Factor For Stunting Among Under Five in Libya. Public Health Nutrition. 2009 Aug: 12 (8), 1141-9.

33. Faiza R, Elnovriza D, Syafianti. Faktor Risiko Kejadian Gizi Buruk paa anak (12-59 Bulan) di Wilayah Kerja Puskesmas Andalas Kecamatan Padang tahun 2007. Media Gizi dan Keluarga. 2007; 31: 80-6.

34.Rasipin. Faktor-faktor yang berhubungan dengan kejadian goiter pada siswa SD diwilayah pertanian. 2011. (Tesis) FKM UNDIP.p: 45-146

35. Purwaningsih, Endang. Pengaruh Suplementasi Seng dan Besi Terhadap pertumbuhan dan Perkembangan, Psikomotorik, dan Kognitif Bayi. 2001 p: 46-4 